\title{
In Vitro Assessment of Antitumor Potential and Combination Effect of Classical and Molecular-targeted Anticancer Drugs
}

\author{
YOSUKE IIJIMA ${ }^{1}$, KENJIRO BANDOW ${ }^{2}$, MOTOHIKO SANO ${ }^{3}$, SHUNSUKE HINO ${ }^{1}$, \\ TAKAHIRO KANEKO ${ }^{1}$, NORIO HORIE ${ }^{1}$ and HIROSHI SAKAGAMI ${ }^{4}$ \\ ${ }^{1}$ Department of Oral and Maxillofacial Surgery, Saitama Medical Center, \\ Saitama Medical University, Kawagoe, Japan; \\ ${ }^{2}$ Division of Biochemistry, Department of Oral Biology and Tissue Engineering, \\ Meikai University School of Dentistry, Sakado, Japan; \\ ${ }^{3}$ Department of Pharmacy Services, Saitama Medical Center, Saitama Medical University, Kawagoe, Japan; \\ ${ }^{4}$ Meikai University Research Institute of Odontology (M-RIO), Sakado, Japan
}

\begin{abstract}
Background/Aim: The aim of the study was to evaluate the antitumor potential and combination effects of chemotherapeutic drugs. Materials and Methods: The cytotoxicity of 20 drip-type classical and molecular-targeted anticancer drugs was examined against 4 human oral squamous cell carcinoma cell lines and 5 human oral normal mesenchymal and epithelial cells. Cell cycle progression was monitored by a cell sorter. Combination effect was evaluated by combination index. Results: Most of the classical anticancer drugs showed much higher antitumor activity than moleculartargeted drugs, except bortezomib. Among 12 classical anticancer drugs, taxanes and gemsitabine showed the highest tumor-specificity (TS) and potency-selectivity expression (PSE) values, whereas platinum analogs showed the least TS value. Combination of two classical or a classical and a moleculartargeted drug showed mostly additive or antagonistic effect. 5$F U$ and cisplatin did not produce a subG $G_{1}$ population, but induced $G_{2} / M$ or $G_{1} / S$ arrest, regardless of the addition of cetuximab. Cetuximab, nibolumab and bortezomib showed potent keratinocyte toxicity. Conclusion: The present TS monitoring system may provide useful information for building up the treatment regimens of anticancer drugs.
\end{abstract}

This article is freely accessible online.

Correspondence to: Yosuke Iijima, Department of Oral and Maxillofacial Surgery, Saitama Medical Center, Saitama Medical University, 1981 Kamoda, Kawagoe, Saitama 350-8550, Japan. Tel: +81 492283687, Fax: +81 492283687, e-mail: yoiijima@saitamamed.ac.jp; Hiroshi Sakagami, Meikai University Research Institute of Odontology (M-RIO), 1-1 Keyakidai, Sakado 350-0283, Saitama, Japan. Tel: +81 492792758, e-mail: sakagami@dent.meikai.ac.jp

Key Words: Anticancer drugs, human oral squamous cell carcinoma cells, tumor-specificity, combination effect, cell cycle analysis, hormesis.
Cancer thermotherapy agents are roughly classified into two groups: (i) classical cytotoxic drugs that act on cell division mechanisms and suppress cell proliferation, and (ii) moleculartargeted drugs that target cancer cell-specific molecules that are essential for cancer cell growth and metastasis (1). The latter group of drugs is expected to show relatively lower side effects than classical cytotoxic drugs.

We have recently reported that classical anticancer drugs exerted both good effect [extremely higher cytotoxicity against human oral squamous cell carcinoma (OSCC) cell lines than human normal oral mesenchymal cells], and bad effect (potent cytotoxicity against human normal oral epithelial cells) $(2,3)$. Recently, moleculartargeted drugs, such as cetuximab (Cmab) and nivolumab (Nmab) have been approved for the treatment of head and neck cancer in Japan (November 10, 2016). However, comparative studies of the direct cytotoxicity of both classical and molecular-targeted drugs against human malignant as well as non-malignant cells has been limited. In contrast to our expectation, several molecular-targeted drugs showed side effects, such as interstitial pneumonia, dermatitis and mucositis/stomatitis (4) and aggravation of cardiotoxicity (5).

It has been reported that many toxic substances and irradiation modulate the growth of cultured cells in a biphasic fashion, growth stimulating or beneficial effects at lower concentrations are known as hormesis (6). If anticancer drugs could induce such hormesis in OSCC, cancer growth may be accelerated.

Based on this background, we investigated the cytotoxicity and hormesis-inducing activity of 12 classical and 8 molecular-targeted anticancer drugs, used for the treatment of cancer patients in our hospital, against 4 human OSCC cell lines (Ca9-22, HSC-2, HSC-3, HSC-4), 3 human normal oral mesenchymal cells [human gingival fibroblast 
(HGF), human periodontal ligament fibroblast (HPLF), human pulp cell (HPC)] and 2 human normal epithelial cells [human oral keratinocyte (HOK), primary human gingival epithelial cell (HGEP)]. Since present treatment regimens of cancer patients usually adopt the combination of more than one anticancer drugs, we also investigated whether such combination treatment induces synergistic cytotoxicity and apoptosis in HSC-2 cell line.

\section{Materials and Methods}

Materials. The following chemicals and reagents were obtained from the indicated companies: Dulbecco's modified Eagle's medium (DMEM) from GIBCO BRL (Grand Island, NY, USA); fetal bovine serum (FBS), 3-(4,5-dimethylthiazol-2-yl)-2,5-diphenyltetrazolium bromide (MTT), actinomycin D and ribonuclease (RNase) A from Sigma-Aldrich Inc. (St. Louis, MO, USA); dimethyl sulfoxide (DMSO), propidium iodide (PI), and $4 \%$ paraformaldehyde phosphate buffer solution from Wako Pure Chem. Ind. (Osaka, Japan); Nonidet P-40 (NP-40) from Nakalai Tesque Inc. (Kyoto, Japan); abraxane (NabPTX) from Taiho Pharmaceutical Co. Ltd. (Tokyo, Japan); pembrolizumab (Pmab) from MSD K. K. (Tokyo, Japan); trastuzumab (Tmab) and bevacizumab (Bmab) from Chugai Pharmaceutical Co., Ltd. (Tokyo, Japan); bortezomib (Bmib) from Janssen Pharmaceutical K, K. (Tokyo, Japan); ramucirumab (Rmab) from Eli Lilly Japan K. K. (Kobe, Japan); oxaliplatin (L-OHP) from Yakult Honsha Co., Ltd. (Tokyo, Japan); elotuzumab (Emab) from Bristol Myers Squibb. K. K., (Tokyo, Japan); gemcitabine (GEM) and cisplatin (CDDP) from Nichi-Iko Pharmaceutical Co. Ltd. (Toyama, Japan); paclitaxel (PTX) from Nipro Corporation. (Osaka, Japan); cetuximab (Cmab) Merck Serono K. K. (Tokyo, Japan); carboplatin (CBDCA) and docetaxel (DTX) from Sawai Pharmaceutical Co. Ltd. (Osaka, Japan); etoposide (ETP) Sandoz K. K. (Yamagata, Japan); 5-fluorouracil (5-FU) and irinotecan (IRT) from Towa Pharmaceutical Co. Ltd. (Osaka, Japan); azacitidine (AZA) from Nippon Shinyaku Co. Ltd. (Kyoto, Japan); nivolumab (Nmab) from Ono Pharmaceutical Co. Ltd. (Osaka, Japan). Culture plastic dishes and plates (96-well) were purchased from Becton Dickinson (Franklin Lakes, NJ, USA).

Cell culture. Human normal oral mesenchymal cells (HGF, HPLF and HPC) were established from the first premolar tooth extracted from the lower jaw of a 12-year-old girl, according to the guidelines of intramural ethic committee (7). Human OSCC cell lines [Ca9-22 (derived from gingival tissue), and HSC-2, HSC-3, and HSC-4 (derived from tongue)] were purchased from Riken Cell Bank (Tsukuba, Japan). These cells were cultured at $37^{\circ} \mathrm{C}$ in DMEM supplemented with $10 \%$ heat-inactivated FBS, 100 units $/ \mathrm{ml}$ penicillin $\mathrm{G}$ and $100 \mu \mathrm{g} / \mathrm{ml}$ streptomycin sulfate, under a humidified $5 \% \mathrm{CO}_{2}$ atmosphere. Human oral keratinocytes (HOK) (purchased from ScienCell Research Laboratories, Carlsbad, CA, USA) were cultured in oral keratinocyte medium. Primary human gingival epithelial cells (HGEP) (purchased from CELLnTEC Advanced Cell Systems AG, Bern, Switzerland) were grown in CnT-PR medium. HGF, HPLF and HPC at 15 20 population doubling levels (PDL), and HOK and HGEP at 7 11 PDL were used in the present study. Cell morphology was checked periodically under a light microscope (EVOS FL; Thermo Fisher Scientific, Waltham, MA, USA).
Assay for cytotoxic activity. Cells were inoculated at $2 \times 10^{3}$ cells $/ 0.1$ $\mathrm{ml}$ in a 96 -microwell plate. After $48 \mathrm{~h}$, the medium was replaced with $0.1 \mathrm{ml}$ of fresh medium containing different concentrations of test compounds. All drip-type anticancer drugs (dissolved in saline) were diluted with culture medium. Cells were incubated further for $48 \mathrm{~h}$ and the relative viable cell number was then determined by the MTT method (3). In brief, control and treated cells were incubated for $2 \mathrm{~h}$ with $0.1 \mathrm{ml}$ of $0.2 \mathrm{mg} / \mathrm{ml} \mathrm{MTT}$ reagent. Then, the MTTcontaining medium was removed, and the purple crystals were lysed with $0.1 \mathrm{ml}$ of DMSO. The relative viable cell number was determined from the absorbance of the cell lysate at $560 \mathrm{~nm}$, using a microplate reader (Infinite F50R; TECAN, Männedorf, Switzerland). The concentration of compound that reduced the viable cell number by $50 \%\left(\mathrm{CC}_{50}\right)$ was determined from the doseresponse curve and the mean value of $\mathrm{CC}_{50}$ for each cell type was calculated from triplicate assays.

Assay for hormesis. The hormetic response was evaluated by the maximum response in each dose-response curve, as described in our previous publication (8).

Calculation of tumor-specificity index (TS). TS was calculated using the following equation: $\mathrm{TS}=$ mean $\mathrm{CC}_{50}$ against three normal oral mesenchymal cells (HGF+HPLF+HPC) /mean $\mathrm{CC}_{50}$ against four OSCC cell lines (Ca9-22+HSC-2+HSC-3 + HSC-4) [(D/B) in Table I]. Since both $\mathrm{Ca} 9-22$ and HGF cells were derived from the gingival tissue (9), the relative sensitivity of these cells was also compared (C/A in Table I).

Calculation of potency-selectivity expression (PSE). For the treatment of cancer patients, both tumor-specificity (TS) and cytotoxicity (reciprocal of $\mathrm{CC}_{50}$ value) of anticancer drugs should be considered. PSE, that is the product of these two factors was calculated using the following equation: $\mathrm{PSE}=100 \times \mathrm{TS} / \mathrm{CC}_{50}$ (tumor cells) [that is, $100 \times \mathrm{D} / \mathrm{B}^{2}(\mathrm{HGF}+\mathrm{HPLF}+\mathrm{HPC} v s$. Ca9-22 + HSC$2+\mathrm{HSC}-3+\mathrm{HSC}-4)$ and $100 \times \mathrm{C} / \mathrm{A}^{2}$ (HGF $v s$. Ca9-22 in Table I) (10).

Assay of combination index. The CompuSyn software program (ComboSyn, Inc.; Paramus, NJ, USA) was used to calculate the combination index (CI) to determine the presence of drug interactions affecting a cell proliferation (11). Briefly, the CI value was determined by the following equation: $\mathrm{CI}=(\%$ decrease of viable cell number by compound $\mathrm{A}+\%$ decrease of viable cell number by compound $\mathrm{B}) /(\%$ decrease of viable cell number by combination of compound A and B). The combination effect was judged "synergistic", "additive" or "antagonistic" when CI was $<1$, 1 and $>1$, respectively (12).

Cell-cycle analysis. Treated and untreated cells (approximately $10^{6}$ cells) were harvested, fixed with $1 \%$ paraformaldehyde in PBS without calcium and magnesium ions $[\mathrm{PBS}(-)]$. Fixed cells were then washed twice with PBS(-) and treated for 30 min with $400 \mu 1$ of $0.2 \mathrm{mg} / \mathrm{ml} \mathrm{RNase} \mathrm{A}$ (preheated for $10 \mathrm{~min}$ at $100^{\circ} \mathrm{C}$ to inactivate DNase) to degrade RNA. Cells were then washed twice with PBS(-) and stained for 15 min with $0.01 \%$ propidium iodide (PI) in the presence of $0.01 \% \mathrm{NP}-40$ in $\mathrm{PBS}(-)$ to prevent cell aggregation. After filtering through Falcon ${ }^{\circledR}$ cell strainers $(40 \mu \mathrm{M})$ (Corning, NY, USA) to remove aggregated cells, PI-stained cells were subjected to cell sorting (SH800 Series; SONY Imaging Products and Solutions Inc., Kanagawa, Japan). Cell-cycle analysis 

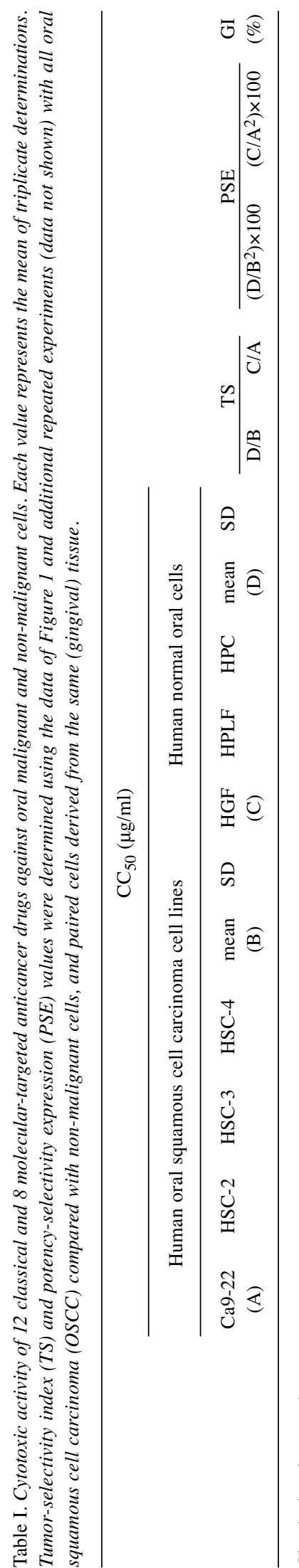

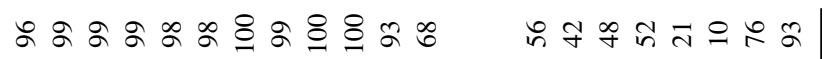

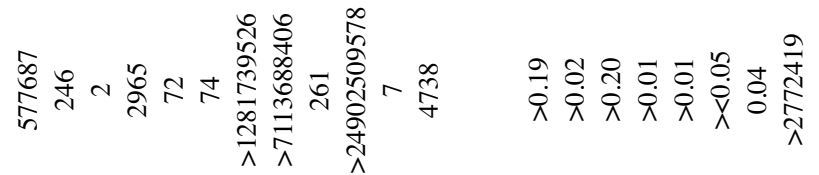

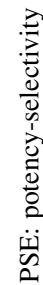

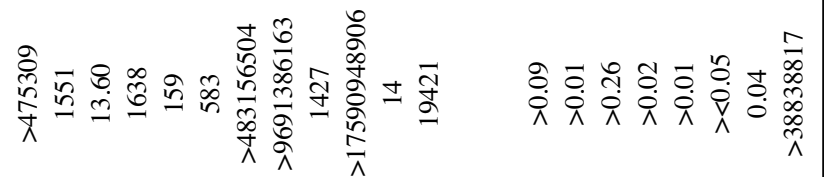

$\mid \overleftarrow{U}$

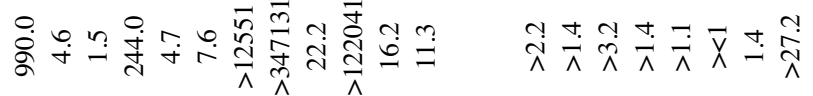

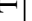

$\stackrel{n}{a}$

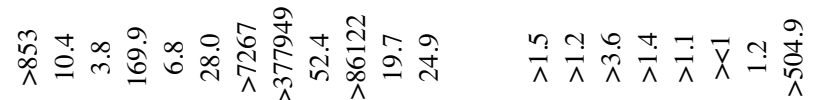

$\ddot{n}$

के

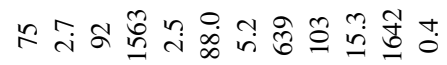

วิํำ

๕ี $\widehat{\Xi}$

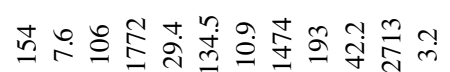

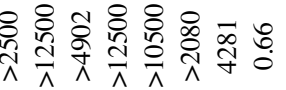

خे + +

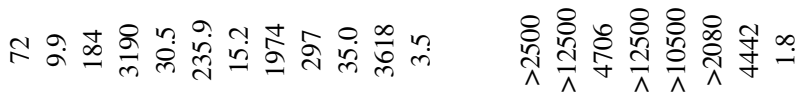

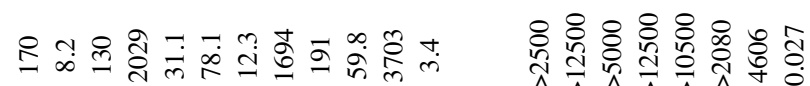

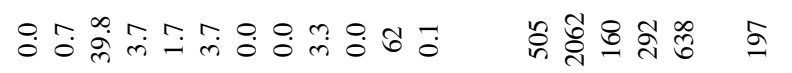

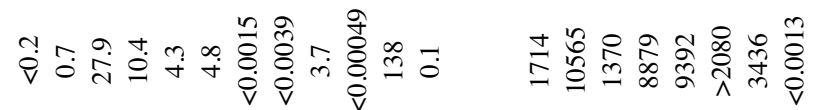

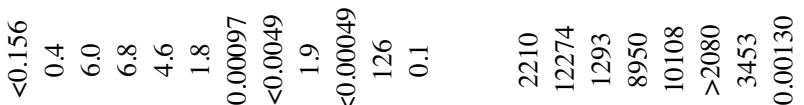

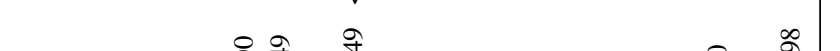

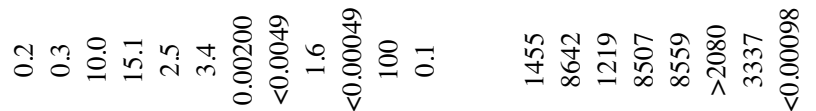

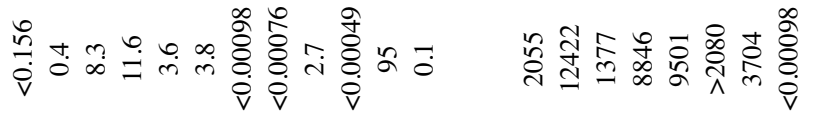

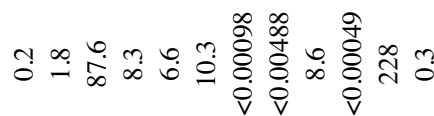

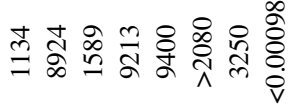

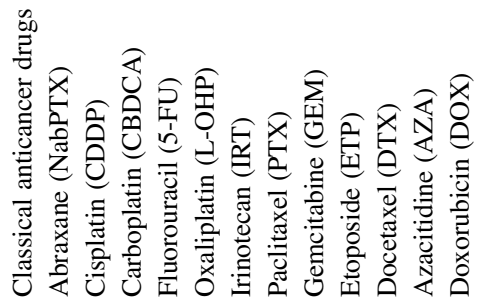

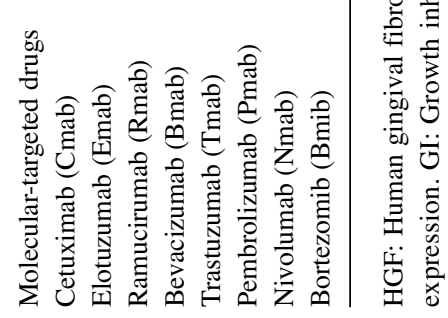


was performed with Cell Sorter Software version 2.1.5. (SONY Imaging Products and Solutions Inc.) (10).

Statistical analysis. Statistical analyses were performed using the Origin pro 2018 software (Origin Lab Corporation, MA, USA). Experimental data are presented as the mean \pm standard deviation (SD) of triplicate determinations. The statistical analysis was performed using one-way analysis of variance (ANOVA) followed by Bonferroni's post-hoc test for multiple comparisons. A value of $p<0.05$ was considered to indicate statistically significant differences. Fitted curves or lines and $\mathrm{R}^{2}$ values were calculated by Microsoft Excel (Windows 10, Microsoft Corporation, Redmond, WA, USA).

\section{Results}

Higher cytotoxicity of classical anticancer drugs against OSCC than molecular targeted drugs except bortezomib. A total of 12 classical anticancer drugs [abraxane (NabPTX), cisplatin (CDDP), carboplatin (CBDCA), fluorouracil (5FU), oxaliplatin (L-OHP), irinotecan (IRT), paclitaxel (PTX), gemcitabine (GEM), etoposide (ETP), docetaxel (DTX), azacitidine (AZA), doxorubicin (DOX)] and 8 molecular targeted drugs [cetuximab (Cmab), elotuzumab (Emab), ramucirumab (Rmab), bevacizumab (Bmab), trastuzumab (Tmab), pembrolizumab (Pmab), nivolumab (Nmab), bortezomib (Bmib)] were investigated for their cytotoxicity against four human OSCC (Ca9-22, HSC-2, HSC-3, HSC-4) and three human normal oral mesenchymal cells (HGF, HPLF, HPC), using the MTT method.

Dose-response curve (Figure 1) demonstrated that all of the classical anticancer drugs induced potent cytotoxicity, with the $50 \%$ cytotoxic concentration $\left(\mathrm{CC}_{50}\right)$ ranging from less than 0.00049 to $138 \mu \mathrm{M}$, reducing the viable cell number by 68 to $100 \%$ (GI in Table I). However, 7 molecular-targeted drugs except Bmib $\left(\mathrm{CC}_{50}=<0.0013 \mu \mathrm{M}\right)$ showed much lower cytotoxicity $\left(\mathrm{CC}_{50}=1714 \sim 10565 \mu \mathrm{M}\right)$, reducing the cell viability only by $10 \sim 76 \%$ (Table I). Among 20 tested compounds, DTX showed the highest cytotoxicity $\left(\mathrm{CC}_{50}=<0.00049 \mu \mathrm{M}\right)$, followed by Bmib $(<0.0013)>\mathrm{PTX}$ $(<0.0015)>\operatorname{GEM}(<0.0039)>\operatorname{DOX}(0.1)>\operatorname{NabPTX}(<0.2)$ $>\operatorname{CDDP}(0.7)>\operatorname{ETP}(3.7)>$ L-OHP $(4.3)>$ IRT $(4.8)>5$ FU $(10.4)>$ CBDCA $(27.9)>\operatorname{AZA}(138)>\operatorname{Rmab}(1370)>$ $\mathrm{Cmab}(1714)>\mathrm{Pmab}(>2080)>\mathrm{Nmab}(3436)>\mathrm{Bmab}$ (8879) > Tmab (9392) > Emab (10565) (Bold: molecular targeted drugs) [(B) in Table I].

Molecular-targeted drugs showed potent keratinocyte toxicity (HOK and HGEP are shown by an open circle and open square, respectively in Figure 2). Cmab showed approximately 2-fold higher cytotoxicity against $\mathrm{HOK}$ $\left(\mathrm{CC}_{50}=1031 \mu \mathrm{g} / \mathrm{ml}\right)$ and HGEP $\left(\mathrm{CC}_{50}=853 \mu \mathrm{g} / \mathrm{ml}\right)$ than against OSCC $\left(\mathrm{CC}_{50}=1714 \mu \mathrm{g} / \mathrm{ml}\right)$ and normal mesenchymal cells $\left(\mathrm{CC}_{50}=>2500 \mu \mathrm{g} / \mathrm{ml}\right)$. Similarly, Nmab showed approximately 5-fold higher cytotoxicity against $\mathrm{HOK}$ $\left(\mathrm{CC}_{50}=680 \mu \mathrm{g} / \mathrm{ml}\right)$ and HGEP $\left(\mathrm{CC}_{50}=898 \mu \mathrm{g} / \mathrm{ml}\right)$ than against OSCC $\left(\mathrm{CC}_{50}=3436 \mu \mathrm{g} / \mathrm{ml}\right)$ and mesenchymal cells $\left(\mathrm{CC}_{50}=4281 \mu \mathrm{g} / \mathrm{ml}\right)$. Bmib showed much higher cytotoxicity to both HOK and HGEP $\left(\mathrm{CC}_{50}<0.003906 \mu \mathrm{g} / \mathrm{m}\right)$.

There was a possibility that the higher sensitivity of OSCC cell lines over normal cells may be due to the different cell density between tumor and normal cells. To test this possibility, the $\mathrm{CC}_{50}$ values of all compounds were plotted as a function of cell density, expressed as the absorbance at $560 \mathrm{~nm}$ of MTTstained untreated OSCC (black color), mesenchymal (gray color) and epithelial cells (white color). Figure 2 shows that the higher sensitivity of OSCC cell lines were observed regardless of cell density, thus eliminating this possibility.

In contrast to our expectation, most of classical and molecular-targeted drugs did not show any apparent hormetic growth stimulation at lower concentration ranges (ND (not detectable) in Table II], except for Cmab, Emab, Rmab and Mmab in Ca9-22 and HSC-2 cells. However, there is a possibility that hormetic stimulatory response (MHSR) can be detected by searching much lower concentration ranges of the test compounds (13).

Higher antitumor potential of classical anticancer drugs than molecular targeted drugs except bortezomib. Since classical anticancer drugs show much less cytotoxicity against human normal oral mesenchymal cells, they showed higher antitumor potential. Antitumor potential was calculated by two parameters: tumor-specificity (TS) and potency-selectivity expression (PSE).

TS was calculated by dividing the $\mathrm{CC}_{50}$ against normal oral mesenchymal cells by the $\mathrm{CC}_{50}$ against aOSCC cells. Calculation of TS with 4 OSCC and 3 normal oral cells (D/B in Table I) yielded a broad distribution pattern ranging from the order of $10^{5}$ to $10^{0}$ : GEM $(\mathrm{TS}=>377949)>\operatorname{DTX}(>86122)$ $>\operatorname{PTX}(>7267)>\operatorname{NabPTX}(>853)>\mathrm{Bmib}(>505)>5-\mathrm{FU}$ $(170)>\operatorname{ETP}(52)>\operatorname{IRT}(\mathrm{TS}=28)>\operatorname{DOX}(\mathrm{TS}=25)>\mathrm{AZA}$ $(\mathrm{TS}=20)>\operatorname{CDDP}(\mathrm{TS}=10)>\mathrm{L}-\mathrm{OHP}(\mathrm{TS}=6.8)>\mathrm{CBDCA}(3.8)$ $>\operatorname{Rmab}(>3.6)>\operatorname{Cmab}(>1.5)>\operatorname{Bmab}(>1.4)>\operatorname{Emab}(>1.2)$ $>\operatorname{Nmab}(>1.2)>\operatorname{Tmab}(>1.1)>$ Pmab $(><1)$. Calculation of TS for Ca9-22 and HGF cells (both derived from gingival tissue) (C/A in Table I) showed similar distribution pattern: GEM $($ TS >347131) > DTX $(>122041)>$ PTX $(>12551)>$ NabPTX $(990)>5$-FU $(244)>$ Bmib $(>27)>\operatorname{ETP}(22)>$ AZA (16) $>$ DOX (11) $>$ IRT (7.6) $>$ L-OHP (4.7) $>$ CDDP $(4.6)>$ $\mathrm{Rmab}(>3.2)>\mathrm{Cmab}(>2.2)>\mathrm{CBDCA}(1.5)>\mathrm{Bmab}$, Nmab, $\operatorname{Emab}(>1.4)>\operatorname{Tmab}(>1.1)>\operatorname{Pmab}(><1)$.

PSE was calculated by dividing TS by $\mathrm{CC}_{50}$ of OSCC and then multiplied by 100 . Calculation of PSE with 4 OSCC and 3 normal oral mesenchymal cells $\left(100 x \mathrm{D} / \mathrm{B}^{2}\right.$ in Table I) yielded a broad distribution pattern ranging from the order of $10^{10}$ to $10^{-2}$ : DTX (PSE >17590948906) $>$ GEM $(>9691386163)>$ PTX $(>483156504)>$ Bmib $(>38838817)$ $>\operatorname{NabPTX}(>475309)>\operatorname{DOX}(19421)>5-\mathrm{FU}(1638)>$ CDDP $(1551)>\operatorname{ETP}(1427)>\operatorname{IRT}(583)>$ L-OHP $(159)>$ 
Iijima et al: Potency and Combination Effect of Anticancer Drugs

Table II. Hormetic response of human oral normal and tumor cells after treatment with classical and molecular-targeted drugs. These values were calculated from the data of Figure 1 and additional repeated experiments (data not shown).

Maximum hormetic response(\%)

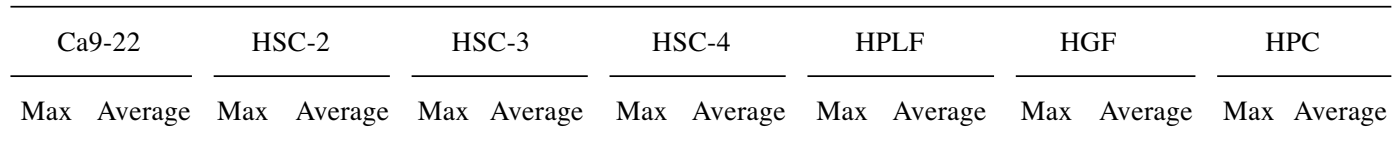

\begin{tabular}{|c|c|c|c|c|c|c|c|c|c|c|c|c|c|c|}
\hline \multicolumn{15}{|c|}{ Classical anticancer drugs } \\
\hline Abraxane (NabPTX) & 18 & 10 & 24 & 9 & 1 & ND & 7 & 1 & 7 & 5 & ND & ND & ND & ND \\
\hline Cisplatin (CDDP) & 8 & 4 & 19 & 19 & ND & ND & 2 & 0 & 6 & 5 & ND & ND & ND & ND \\
\hline Carboplatin (CBDCA) & 30 & 26 & 4 & 0 & 6 & ND & 0 & ND & 9 & 6 & ND & ND & ND & ND \\
\hline Fluorouracil (5-FU) & 10 & 6 & 14 & 9 & 5 & 0 & ND & ND & 1 & ND & ND & ND & ND & ND \\
\hline Oxaliplatin (L-OHP) & 17 & 14 & 23 & 17 & 27 & 19 & ND & ND & 12 & 8 & ND & ND & ND & ND \\
\hline Irinotecan (IRT) & 52 & 43 & 19 & 15 & 2 & 0 & ND & ND & 11 & 8 & ND & ND & ND & ND \\
\hline Paclitaxel (PTX) & ND & ND & ND & ND & ND & ND & ND & ND & ND & ND & ND & ND & ND & ND \\
\hline Gemcitabine (GEM) & ND & ND & ND & ND & ND & ND & ND & ND & 12 & 10 & ND & ND & ND & ND \\
\hline Etoposide (ETP) & 15 & 10 & 19 & 14 & ND & ND & 3 & ND & 6 & 4 & ND & ND & ND & ND \\
\hline Docetaxel (DTX) & ND & ND & ND & ND & ND & ND & ND & ND & 13 & 8 & ND & ND & ND & ND \\
\hline Azacitidine (AZA) & 45 & 25 & 30 & 26 & ND & ND & ND & ND & 23 & 19 & ND & ND & ND & ND \\
\hline \multicolumn{15}{|c|}{ Molecular targeted drugs } \\
\hline Cetuximab (Cmab) & 70 & 52 & 46 & 11 & ND & ND & ND & ND & 33 & 22 & ND & ND & 3 & ND \\
\hline Elotuzumab (Emab) & 69 & 43 & 90 & 48 & ND & ND & ND & ND & 28 & 20 & 2 & ND & ND & ND \\
\hline Ramucirumab (Rmab) & 39 & 28 & 72 & 38 & 5 & ND & 0 & ND & 28 & 23 & ND & ND & ND & ND \\
\hline Bevacizumab (Bmab) & 215 & 192 & 54 & 27 & ND & ND & 0 & ND & 18 & 12 & 7 & 1 & ND & ND \\
\hline Bortezomib (Bmib) & ND & ND & ND & ND & ND & ND & ND & ND & ND & ND & ND & ND & ND & ND \\
\hline
\end{tabular}

AZA, CBDCA $(14)>\operatorname{Rmab}(>0.26)>\mathrm{Cmab}(>0.09)>$ $\mathrm{Nmab}(0.04)>\operatorname{Bmab}(>0.02)>$ Emab, Tmab $(>0.01)>$ Pmab $(><0.05)$. Calculation of PSE with Ca9-22 and HGF cells $\left(100 \times \mathrm{xC} / \mathrm{A}^{2}\right.$ in Table I) showed similar distribution pattern: DTX (PSE >24902509578) > GEM (>7113688406) $>\operatorname{PTX}(>1281739526)>$ Bmib $(>2772419)>$ NabPTX $(577687)>\operatorname{DOX}(4738)>5$-FU $(2965)>\operatorname{ETP}(261)>$ CDDP (246) $>$ IRT (74) $>$ L-OHP (72) $>$ AZA (7) $>$ CBDCA (2) $>\operatorname{Rmab}(>0.20)>\mathrm{Cmab}(>0.19)>\operatorname{Pmab}(><0.05)>$ Nmab $(0.04)>$ Emab $(>0.02)>$ Bmab, Tmab $(>0.01)$.

These data demonstrated that classical antitumor drugs showed much higher antitumor activity, measured by either by TS or PSE, than molecular-targeted drugs except for Bmid.

Correlation between anticancer potential and cytotoxicity. When the $\mathrm{CC}_{50}$ values (in log scale) of the 20 anticancer drugs were plotted as a function of the TS or log PSE value (in $\log$ scale), well-fitted regression lines were produced with $\mathrm{R}^{2}$ value of $0.7753(\mathrm{D} / \mathrm{B}), 0.6363(\mathrm{C} / \mathrm{A}), 0.9619\left(\mathrm{D} / \mathrm{B}^{2}\right) \times 100$, $\left.0.0214\left(\mathrm{C} / \mathrm{A}^{2}\right) \times 100\right)$ (Figure 3). All 20 anticancer drugs including Bmib lined up on the same line. This indicates that the anti-cancer activity, either TS or PSE, can be estimated by measuring the cytotoxic activity $\left(\mathrm{CC}_{50}\right)$.

Additive or antagonistic interaction between classical and molecular-targeted anticancer drugs. In order to investigate the combination effect of two anticancer drugs, HSC-2 cells were incubated for $48 \mathrm{~h}$ with various concentrations of each compound (data not shown). Drug interaction between the two compounds, such as synergism, additivity and antagonism, can be monitored by combination index (CI) (Figure 4). Combination of Cmab (78 $\mu \mathrm{g} / \mathrm{ml})$ with NabPTX, CDDP, 5FU, CBDCA, L-OHP, or 5-FU $(0.05 \sim 125 \mu \mathrm{g} / \mathrm{ml})$ produced the $\mathrm{CI}$ index of nearly 1 , indicating additive interaction in HSC-2 cells. At higher concentrations of Cmab, the CI exceeded 1, suggesting antagonistic interaction (Figure 4A). Similarly, combination of Nmab $(156 \mu \mathrm{g} / \mathrm{ml})$ and 5-FU $(0.5 \sim 125 \mu \mathrm{g} / \mathrm{ml})$ produced additive interaction, whereas higher concentrations of Nmab produced antagonistic interaction (Figure 4A). Combination of 5-FU $(0.5 \mu \mathrm{g} / \mathrm{ml})$ with GEM $(6-100 \mu \mathrm{g} / \mathrm{ml})$, DOX $(0.3-5 \mu \mathrm{g} / \mathrm{ml})$, IRT $(3 \mu \mathrm{g} / \mathrm{ml}), \operatorname{CDDP}(0.8 \mu \mathrm{g} / \mathrm{ml})$, AZA $(16 \mu \mathrm{g} / \mathrm{ml})$, L-OHP ( 0.8-12.5 $\mu \mathrm{g} / \mathrm{ml})$, NabPTX $(0.8 \mu \mathrm{g} / \mathrm{ml})$ or CBDCA $(78 \mu \mathrm{g} / \mathrm{ml})$ produced additive interaction, whereas higher concentrations of 5-FU showed antagonistic interaction in HSC-2 cells (Figure 4B).

Combination of Cmab and CDDP, 5-FU or NabPTX, and combination of $\mathrm{CBDCA}$ and 5-FU produced additive or antagonistic interaction on Ca9-22 cells (Figure 4C).

Cell cycle arrest induced by Cmab combined with CDDP or $5-F U$. Cell cycle analysis (Figure 5) demonstrated that treatment of HSC-2 cells with Cmab (625 $\mu \mathrm{g} / \mathrm{ml})$, CDDP $(0.4$ 


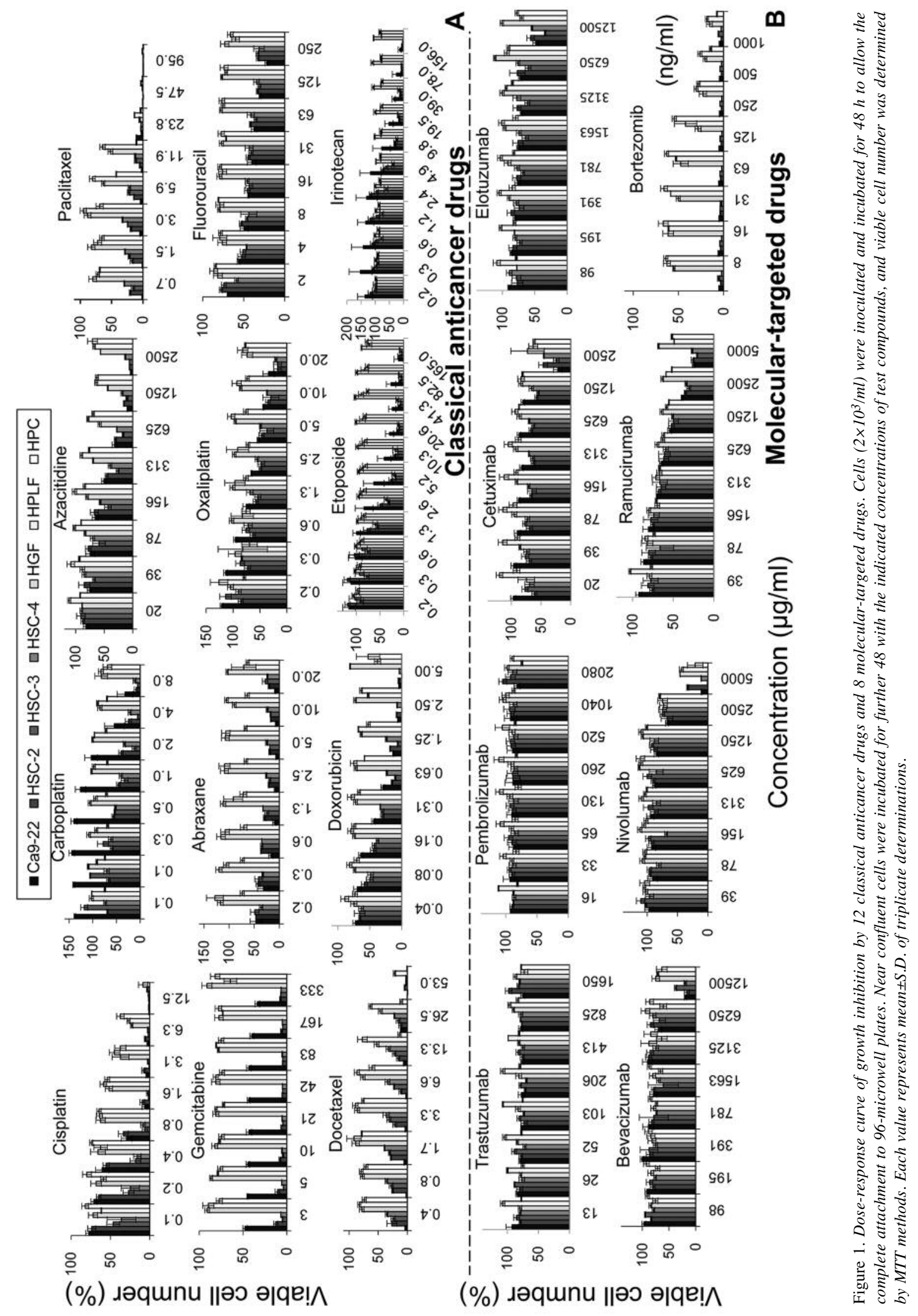




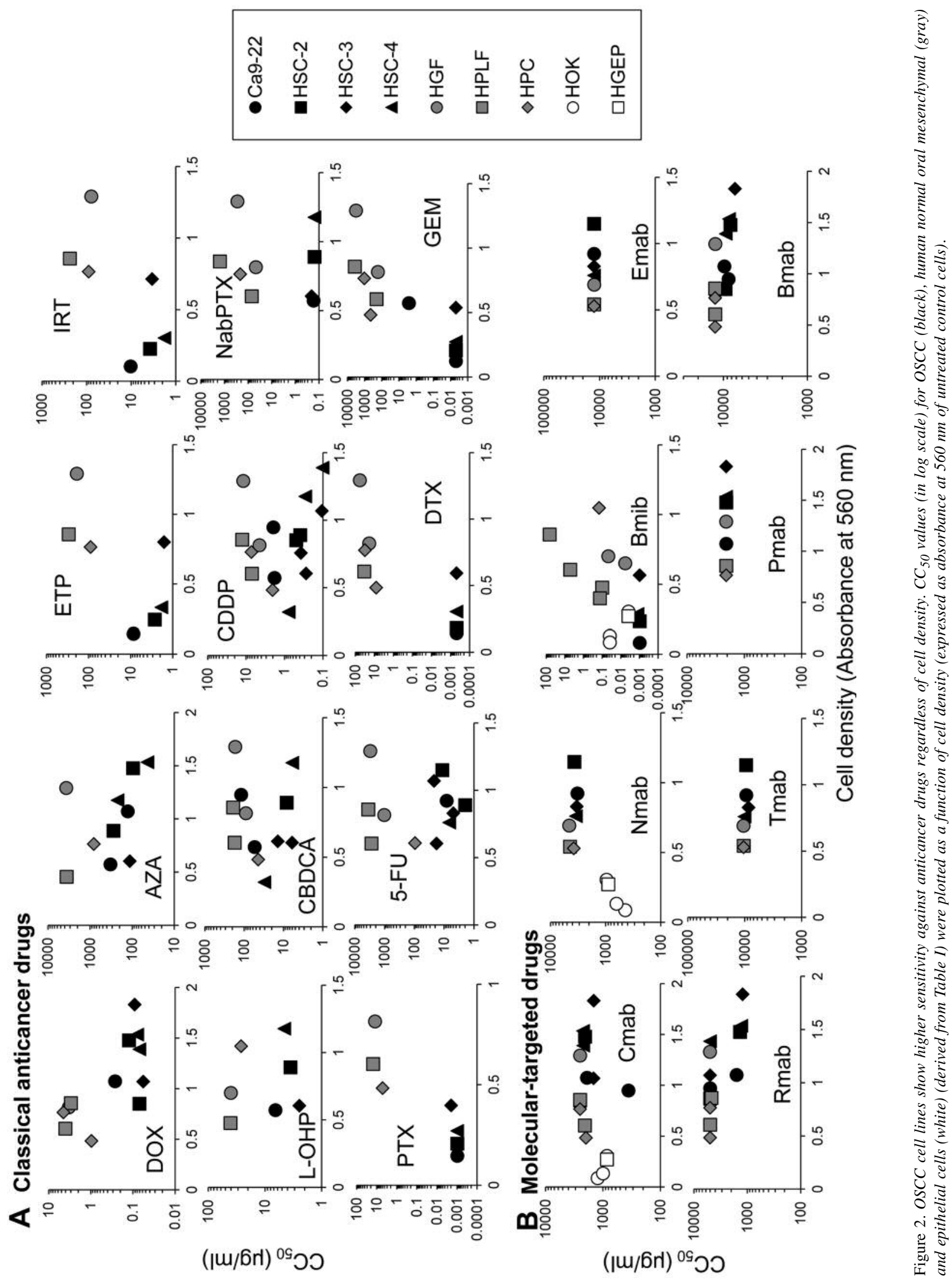




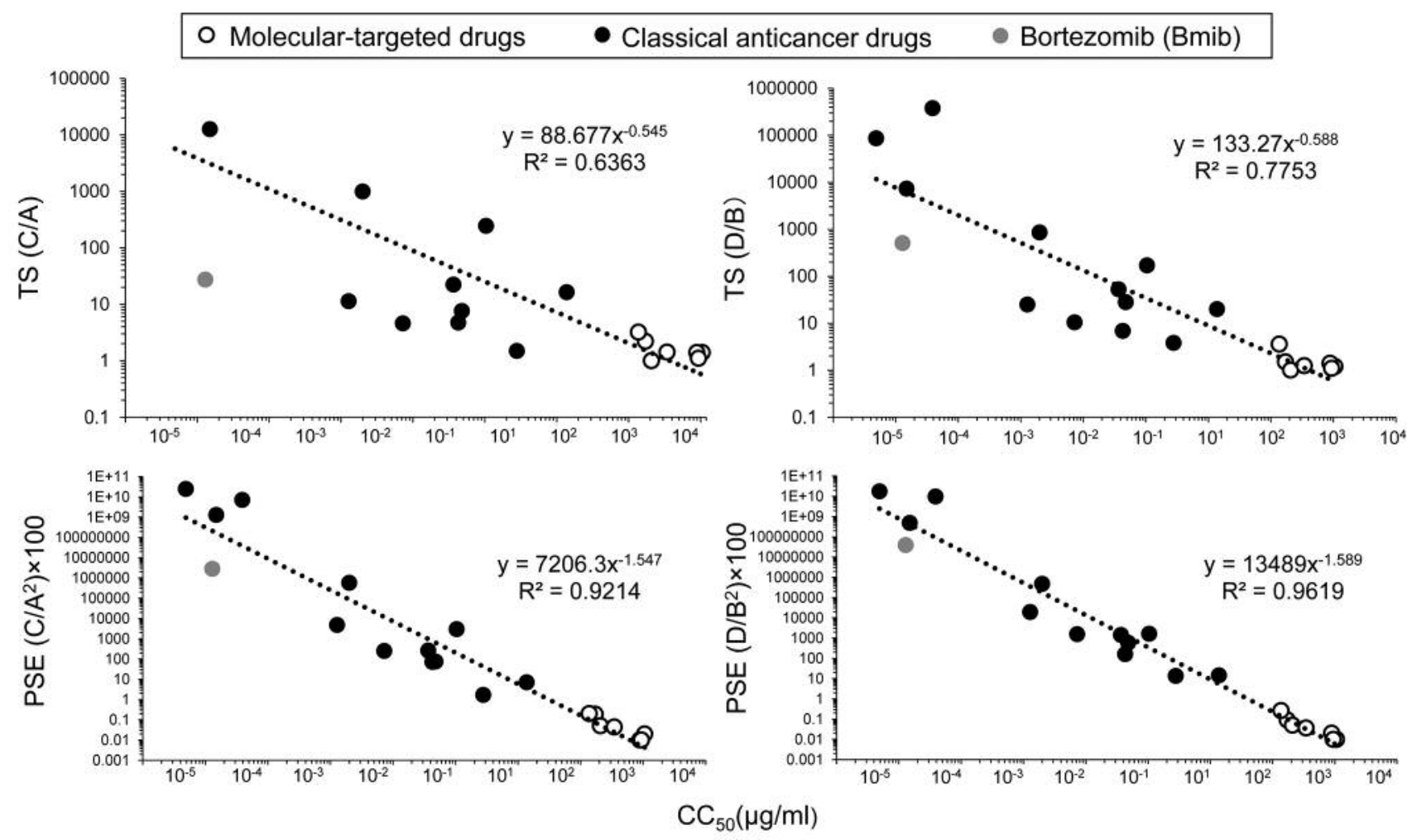

Figure 3. Correlation of antitumor activity (evaluated by TS or PSE) and the cytotoxic anticancer potential of the 20 anticancer drugs. TS or PSE values (in log scale) of 12 classical anticancer drugs (black circle), 7 molecular-targeted drugs (white circle) and bortezomib (gray circle) were plotted vs their cytotoxicity $\left[C C_{50}\right.$ value (in log scale) derived from Table I]. Fitted curves or lines and $R^{2}$ values were calculated as described in Materials and Methods.

and $0.8 \mu \mathrm{g} / \mathrm{ml}$, corresponding to $1 \times$ and $\left.2 \times \mathrm{CC}_{50}\right), 5-\mathrm{FU}(11.6$ and $23.6 \mu \mathrm{g} / \mathrm{ml}$, corresponding to $1 \times$ and $2 \times \mathrm{CC}_{50}$ ) failed to induce accumulation of cell population in the $\mathrm{subG}_{1}$ phase (apoptosis marker), in contrast to actinomycin D $(1 \mu \mathrm{M})$ (positive control). CDDP dose-dependently reduced the $\mathrm{G}_{1}$ population but increased the $S$ and $G_{2} / M$ population, suggesting growth arrest at $\mathrm{G}_{2} / \mathrm{M}$. On the other hand, 5-FU slightly increased the number of cells in the $G_{1}$ and $S$ phases, and reduced the number of cells in the $G_{2} / M$ phase, suggesting the inhibition of entry into $\mathrm{S}$ phase. Combination of $\mathrm{Cmab}$ and CDDP or 5-FU produced nearly the same distribution pattern observed in cells treated with CDDP or 5-FU alone. This suggested that cell cycle distribution is controlled mainly by classical anticancer drugs rather than by molecular-targeted drugs.

\section{Discussion}

We have investigated the tumor-specificity of 20 anticancer drugs used clinically as drip treatment of cancer patients. These water-soluble samples can be applied to cells, without the use of organic solvent such as DMSO, and thus provides much reliable information regarding the cytotoxicity of each drug. The possible difference of antitumor potency and action mechanism between water-soluble and water-insoluble compounds remains to be investigated, since many researchers studying in vitro anticancer activity have used fat-soluble anticancer drugs, dissolved with organic solvent such as DMSO.

The present study demonstrated that among 12 classical anticancer drugs, taxanes such as PTX (TS $>7267$, PSE>483156504) and DTX (TS>86122, PSE>17590948908), and GEM (TS> 377949, PSE $>$ 9691386163) showed the highest tumor-specificity, suggesting its potent anticancer activity. However, platinum analogs such as CDDP $(\mathrm{TS}=10$; $\mathrm{PSE}=1551), \mathrm{CBDCA}(\mathrm{TS}=4, \mathrm{PSE}=14)$ and $\mathrm{L}-\mathrm{OHP}(\mathrm{TS}=7$, $\mathrm{PSE}=159$ ) showed surprisingly low tumor-specificity. Taxanes and platinum analogs are well known to show neurotoxicity (14). These data may explain why adding taxanes to GEM and platinum improved overall survival but worsened neurotoxicity (15). These suggest the importance of more detailed in vitro study that can propose the optimal dose for the treatment.

Among the 8 molecular-targeted drugs, only Bmib, proteasome inhibitor, showed excellent tumor-specificity (TS>505, PSE > 38838817) (Table I). Bmib is mainly used 


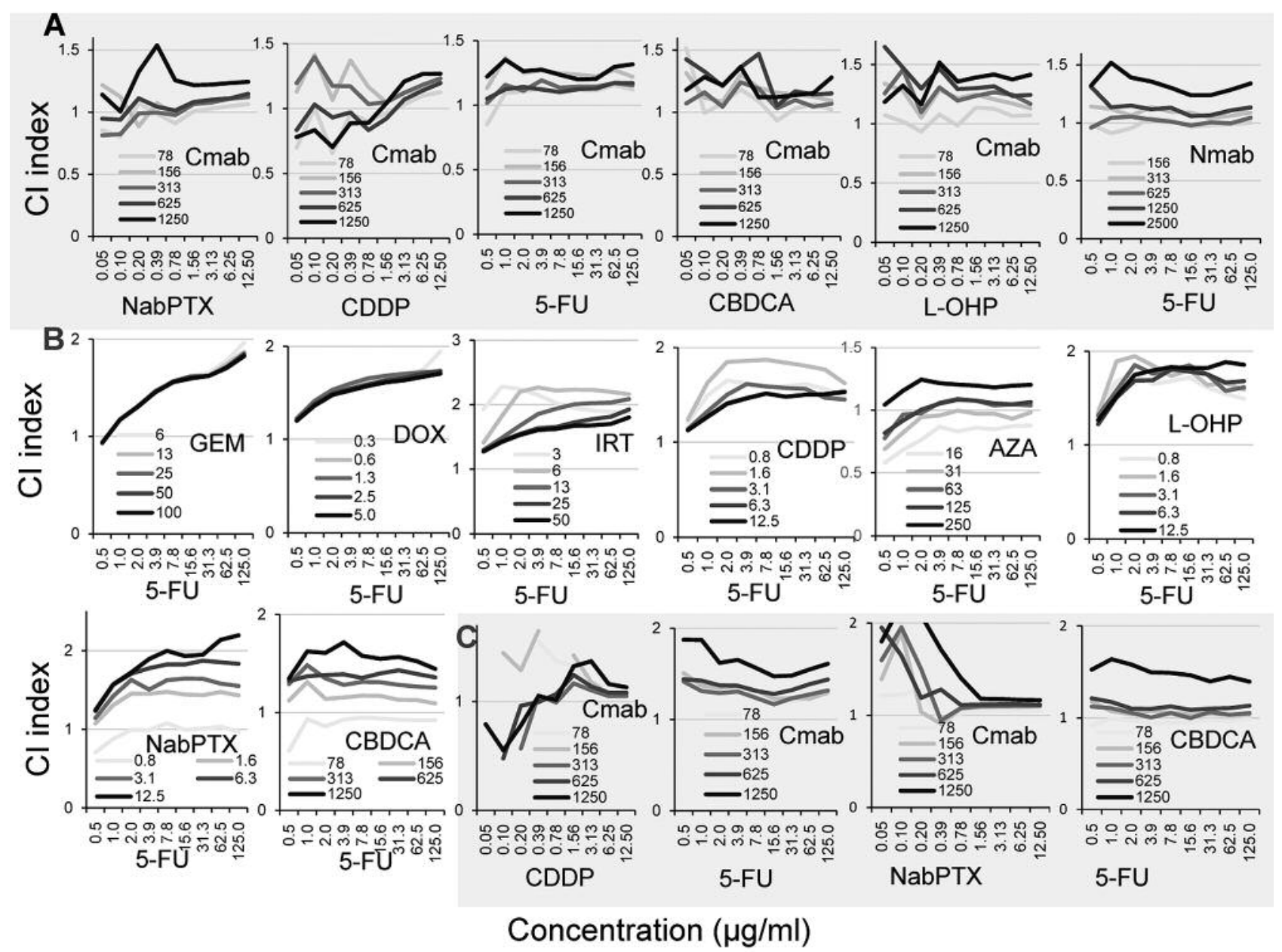

Figure 4. Combination effect of two types of anticancer drugs. HSC-2 cells were incubated for $48 \mathrm{~h}$ with the indicated sets of compounds, and CI index was then determined as described in Materials and Methods.

as a therapeutic agent for refractory multiple myeloma in hematology clinic, due to its potent anti-tumor activity and yet-unknown biological function (16). It has been reported that Bmib caused the high incidence of neutropenia and stomatitis (17), peripheral neuropathy (18) and epidermal necrolysis (19). We also found potent cytotoxicity of Bmib against OSCC cell lines as well as normal oral cells, especially oral keratinocytes. Therefore, application of the cytotoxic chemotherapeutic agents in combination with Bmib in immuno-compromised patients could further increase the incidence of side effects (16). The other 7 molecular-targeted drugs (Cmab, Emab, Rmab, Bmab, Tmab, Pmab, Nmab) showed much lower antitumor potency (TS=1 3.6; PSE $=0.01 \sim 0.2$ ), and some of them (Cmab and $\mathrm{Nmab}$ ) showed potent keratinocyte toxicity (Figure 2 and unpublished data). Clinical investigation revealed the incidence of dermatitis and acneiform rash (20) (Cmab) and myocarditis with or without a complete heart block by Cmab and Nmab (21).

The present study demonstrated that Cmab and classical anticancer drugs, when added simultaneously, inhibited the growth of HSC-2 cells in an additive fashion (Figure 4). This supports the present regimen that recommends administration of Cmab first, followed by classic anticancer drugs, considering the absence of synergism in the simultaneous administration. Furthermore, the popular FOLFOX regiments for treatment of colon cancer patients use L-OHP and 5-FU sequentially (22), and FOLFIRI regimen uses IRT and 5-FU sequentially (23). We also observed that combination of 5-FU and other classical anticancer drugs produced rather antagonistic interaction, that could increase the incidence of side effects. Based on these results, administration of a single chemotherapeutic agent, rather than a combination seemed to be preferable. To 


\section{A Single treatment}
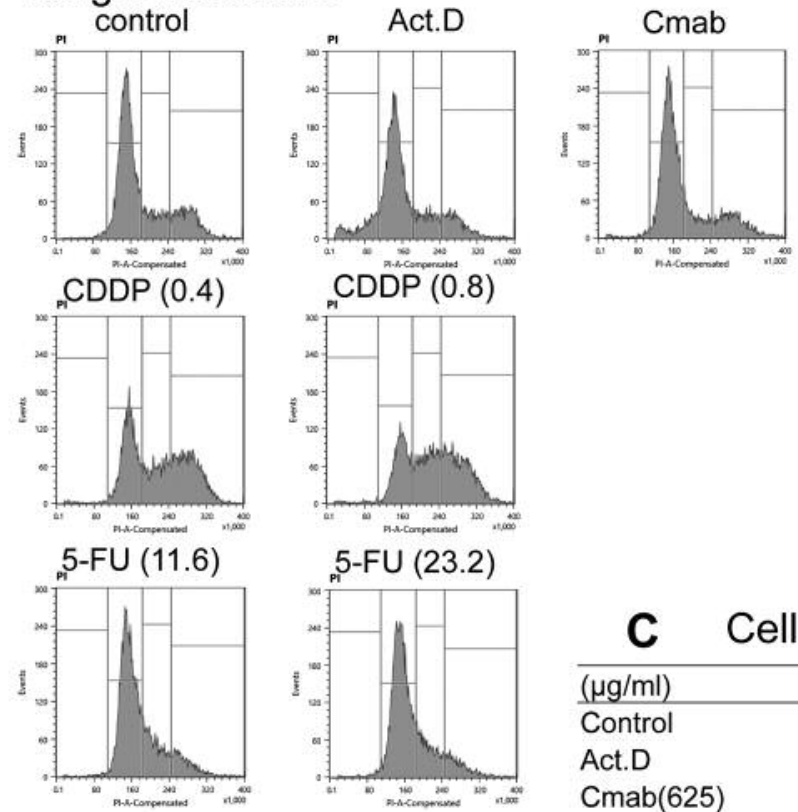

B Combination treatment with $\mathrm{Cmab}$

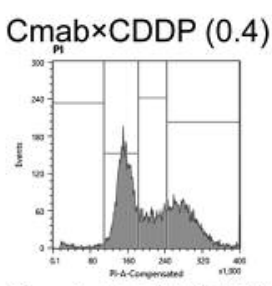

$\mathrm{Cmab} \times 5-\mathrm{FU}(11.6)$

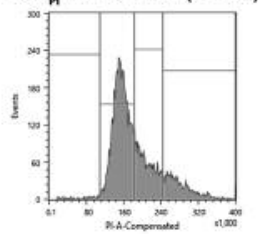

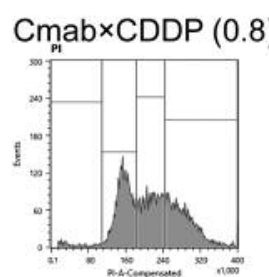

$\mathrm{Cmab} \times 5-\mathrm{FU}(23.2)$

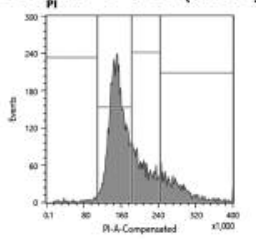

\section{Cell cycle distribution (\%)}

\begin{tabular}{|c|c|c|c|c|}
\hline$(\mu \mathrm{g} / \mathrm{ml})$ & subG1 & G1 & $\mathrm{S}$ & G2/M \\
\hline Control & $1.80 \pm 0.22$ & $62.11 \pm 0.19$ & $15.78 \pm 0.61$ & $21.29 \pm 0.41$ \\
\hline Act.D & $12.51 \pm 0.25^{*}$ & $58.33 \pm 0.59$ & $14.69 \pm 0.44$ & $15.82 \pm 0.75$ \\
\hline $\operatorname{mab}(625)$ & $2.56 \pm 0.02$ & $64.07 \pm 0.17$ & $14.15 \pm 0.52$ & $20.50 \pm 0.22$ \\
\hline $\operatorname{CDDP}(0.4)$ & $1.55 \pm 0.05$ & $37.62 \pm 0.46^{*}$ & $23.73 \pm 0.12^{*}$ & $38.43 \pm 0.46^{*}$ \\
\hline $\operatorname{CDDP}(0.8)$ & $1.55 \pm 0.24$ & $29.54 \pm 0.77^{*}$ & $30.65 \pm 0.50^{*}$ & $39.78 \pm 1.20^{*}$ \\
\hline $5-F U($ & 1.71 & $66.05 \pm 1.19$ & $21.39 \pm 0.54 *$ & $12.25 \pm 0.83^{*}$ \\
\hline $5-\mathrm{FU}(23.2)$ & 2.03 & 67.2 & $20.25 \pm 0.23^{*}$ & $11.73 \pm 0.64^{*}$ \\
\hline $\mathrm{Cmab}(62$ & 2.55 & $42.40 \pm 0.37^{*}$ & $21.25 \pm 0.32^{*}$ & $35.13 \pm 0.79^{*}$ \\
\hline $\operatorname{Cmab}(625) \times \operatorname{CDDP}(0.8)$ & $3.24 \pm 0.27$ & $34.52 \pm 0.88^{*}$ & $30.66 \pm 0.50 *$ & $35.15 \pm 0.48^{*}$ \\
\hline $\mathrm{Cmab}(625) \times 5-\mathrm{FU}(11.6)$ & $1.93 \pm 0.07$ & $60.14 \pm 0.87$ & $24.32 \pm 0.28^{*}$ & $15.11 \pm 0.63^{*}$ \\
\hline $\mathrm{Cmab}(625) \times 5-\mathrm{FU}(23.2)$ & $2.04 \pm 0.05$ & $59.90 \pm 0.31$ & $23.58 \pm 0.33^{*}$ & $15.83 \pm 0.71^{*}$ \\
\hline
\end{tabular}

Figure 5. Cell-cycle analysis of HSC-2 cells treated with various anticancer drugs. Cells were incubated for 24 h with actinomycin D (positive control), Cmab $(625 \mu \mathrm{g} / \mathrm{ml}), C D D P(0.4,0.8 \mu \mathrm{g} / \mathrm{ml})$ or $5-\mathrm{FU}(11.6,23.2 \mu \mathrm{g} / \mathrm{ml})$ alone or in combination, and then assessed for cell-cycle distribution by cell sorting. The differences between groups were evaluated by one-way analysis of variance (ANOVA) followed by Bonferroni's post-hoc test for multiple comparisons. A value of * $p<0.05$ compared with positive control.

find drugs with synergistic effect, which include the concomitant use of radiation therapy (24) is another choice.

Lastly, we investigated the correlation between the maximum serum concentration (Cmax) after administration of the indicated doses (cited from the interview form from the supplier pharmaceutical companies) (Table III), and in vitro cytotoxicity against OSCC (B) and normal cells (D) (derived from Table I). When Cmax of each compound was divided by the $\mathrm{CC}_{50}$ for normal cells (D), most of the compounds except CDDP and DOX showed the value below 1 (Cmax/D in Table III), indicating that clinical administration may not be so harmful. When the Cmax was divided by the $\mathrm{CC}_{50}$ for OSCC, NabPTX, PTX, GEM, DTX and Bmib showed very high values $(\mathrm{Cmax} / \mathrm{B}=100,283$, 5590,4082 and 172, respectively), indicating that clinical administration of these drugs can yield an efficient anticancer effect.

\section{Conclusion}

The present study with a total of 20 clinically used antitumor drugs demonstrated that classical antitumor drugs showed higher cytotoxicity and antitumor potential as compared with molecular-targeted drugs except bortezomib. When the antitumor potential of all compounds (either TS or PSE) was plotted as a function of cytotoxicity $\left(\mathrm{CC}_{50}\right)$, highly significant correlation curves were produced. This suggests that the antitumor potential of any unknown anticancer drug candidate can be easily estimated from this regression line. Simultaneous addition of both types of anticancer drugs failed to induce apoptosis nor synergistic growth inhibition, suggesting the necessity of reconsidering the antitumor potency of the present combination regimens with more than two compounds. The present TS monitoring system may provide useful information for building up the treatment regimens of anticancer drugs. 
Table III. Correlation between clinical data of maximum serum concentration (Cmax) and cytotoxicity of 20 anticancer drugs (determined in this study). Cmax was obtained from the interview form from the supplier. $C_{50}$ for OSCC (B) and normal oral cells $(D)$ are derived from Table I.

\begin{tabular}{|c|c|c|c|c|c|c|}
\hline & Dose & $\begin{array}{l}\text { Serum } \\
\text { conc. } \\
\text { Cmax }\end{array}$ & $\begin{array}{c}\mathrm{CC}_{50} \\
(\mathrm{OSCC}) \\
\mathrm{B}\end{array}$ & $\begin{array}{c}\mathrm{CC}_{50} \\
\text { (normal cell) } \\
\text { D }\end{array}$ & $\begin{array}{c}\text { Ratio } \\
\text { (OSCC) } \\
\text { Cmax/B }\end{array}$ & $\begin{array}{c}\text { Ratio } \\
\text { (normal cell) } \\
\mathrm{Cmax} / \mathrm{D}\end{array}$ \\
\hline Classical anticancer drugs & $\mathrm{mg} / \mathrm{m}^{2}$ & $\mu \mathrm{g} / \mathrm{ml}$ & $\mu \mathrm{g} / \mathrm{ml}$ & $\mu \mathrm{g} / \mathrm{ml}$ & & \\
\hline Abraxane (NabPTX) & 260 & 20.0 & 0.200 & 153.7 & 100.0 & 0.13 \\
\hline Cisplatin (CDDP) & 100 & 17.1 & 0.726 & 7.6 & 23.6 & 2.3 \\
\hline Carboplatin (CBDCA) & 400 & 5.9 & 27.948 & 106.2 & 0.2 & 0.1 \\
\hline Fluorouracil (5-FU) & 1000 & 15.3 & 10.430 & 1771.7 & 1.5 & 0.01 \\
\hline Oxaliplatin (L-OHP) & 85 & 0.6 & 4.293 & 29.4 & 0.1 & 0.02 \\
\hline Irinotecan (IRT) & 180 & 9.1 & 4.802 & 134.5 & 1.9 & 0.07 \\
\hline Paclitaxel (PTX) & 100 & 0.4 & 0.0015 & 10.9 & 283.3 & 0.04 \\
\hline Gemcitabine (GEM) & 1000 & 21.8 & 0.0039 & 1474.1 & 5589.7 & 0.01 \\
\hline Etoposide (ETP) & 100 & 4.4 & 3.674 & 192.6 & 1.2 & 0.02 \\
\hline Docetaxel (DTX) & 60 & 2.0 & 0.00049 & 42.2 & 4081.6 & 0.05 \\
\hline Azacitidine (AZA) & 75 & 4.2 & 137.5 & 2712.5 & 0.0 & 0.002 \\
\hline Doxorubicin (DOX) & 60 & 3.3 & 0.13 & 3.2 & 25.9 & 1.0 \\
\hline Molecular-targeted drugs & $\mathrm{mg} / \mathrm{kg}$ & $\mu \mathrm{g} / \mathrm{ml}$ & $\mu \mathrm{g} / \mathrm{ml}$ & $\mu \mathrm{g} / \mathrm{ml}$ & & \\
\hline Cetuximab (Cmab) & $400\left(\mathrm{mg} / \mathrm{m}^{2}\right)$ & 287.2 & 1713.5 & 2500.0 & 0.2 & 0.11 \\
\hline Elotuzumab (Emab) & 10 & 24.0 & 10565.2 & 12500.0 & 0.002 & 0.002 \\
\hline Ramucirumab (Rmab) & 8 & 16.0 & 1369.5 & 4902.0 & 0.012 & 0.003 \\
\hline Bevacizumab (Bmab) & 5 & 1429.0 & 8879.2 & 12500.0 & 0.161 & 0.114 \\
\hline Trastuzumab (Tmab) & 8 & 128.0 & 9392.0 & 10500.0 & 0.014 & 0.012 \\
\hline Pembrolizumab (Pmab) & & 186.0 & 2080.0 & 2080.0 & 0.089 & 0.089 \\
\hline Nivolumab (Nmab) & & 68.8 & 3436.2 & 4280.8 & 0.020 & 0.016 \\
\hline Bortezomib (Bmib) & $1.3\left(\mathrm{mg} / \mathrm{m}^{2}\right)$ & 0.2 & 0.0013 & 0.7 & 171.5 & 0.34 \\
\hline
\end{tabular}

\section{Conflicts of Interest}

The Authors confirm that there are no known conflicts of interest associated with this publication and there has been no significant financial support for this work that could have influenced its outcome.

\section{Authors' Contributions}

Y.I. and H.S. performed most of the experiments of the present study and wrote the manuscript. K.B. performed the cell cycle analysis and reviewed the manuscript. S.H., M.S., T.K., N.H. and H.S. provided the interpretation of experimental results, and edited the manuscript.

\section{Acknowledgements}

This work was partially supported by KAKENHI from the Japan Society for the Promotion of Science (JSPS) (16K11519).

\section{References}

1 Brunton LL, Hilal-Dandan R, Knollman BC, Goodman \& Gilman's: The pharmacological basis of therapeutics. Thirteenth Edition. New York: McGraw-Hill Education Inc; 2018: Chapter 66: cytotoxic drugs, Chapter 67: Pathway-Targeted Therapies.
2 Sakagami H, Watanabe T, Hoshino T, Hoshino T, Suda N, Mori K, Yasui T, Yamauchi N, Kashiwagi H, Gomi T, Oizumi T, Nagai J, Uesawa Y, Takao K and Sugita Y: Recent progress of basic studies of natural products and their dental application. Medicines (Basel) 6(1) pii: E4, 2018. PMID: 30585249. DOI: 10.3390/medicines6010004

3 Sakagami H, Okudaira N, Masuda Y, Amano O, Yokose S, Kanda Y, Suguro M, Natori T, Oizumi $H$ and Oizumi T: Induction of apoptosis in human oral keratinocyte by doxorubicin. Anticancer Res 37(3): 1023-1029, 2017. PMID: 28314260. DOI: 10.21873 /anticanres.11412

4 Hirasawa K, Okamoto I, Motohashi R, Sato M, Takase S, Agata A, Takeda A and Tsukahara K: The efficiency and adverse events of radiotherapy with cetuximab for Japanese head and neck cancer patients. Auris Nasus Larynx 44(6): 724-728, 2017. PMID: 28237712. DOI: 10.1016/j.anl.2017.01.005

5 Rochette L, Guenancia C, Gudjoncik A, Hachet O, Zeller M, Cottin $\mathrm{Y}$ and Vergely C: Anthracyclines/trastuzumab: new aspects of cardiotoxicity and molecular mechanisms. Trends Pharmacol Sci 36(3): 326-348, 2015. PMID: 25895646. DOI: 10.1016/j.tips.2015.03.005

6 Calabrese EJ: Paradigm lost, paradigm found: the re-emergence of hormesis as a fundamental dose response model in the toxicological sciences. Environ Pollut 138(3): 379-411, 2005. PMID: 16098930. DOI: 10.1016/j.envpol.2004.10.001

7 Kantoh K, Ono M, Nakamura Y, Nakamura Y, Hashimoto K, Sakagami $\mathrm{H}$ and Wakabayashi $\mathrm{H}$ : Hormetic and anti-radiation 
effects of tropolone-related compounds. In Vivo 24(6): 843-852, 2010. PMID: 21164042.

8 Wakabayashi H, Narita T, Suga A and Sakagami H: Hormetic response of cultured normal and tumor cells to 2-aminotropone derivatives. In Vivo 24(1): 39-44, 2010. PMID: 20133973.

9 Horikoshi M, Kimura Y, Nagura H, Ono T and Ito H: A new human cell line derived from human carcinoma of the gingiva. I. Its establishment and morphological studies. Jpn J Oral Maxillofac Surg 20: 100-106, 1974. PMID: 4549822. DOI: 10.5794/jjoms.20.100

10 Shi H, Nagai J, Sakatsume T, Bandow K, Okudaira N, Uesawa Y, Sakagami H, Tomomura M, Tomomura A, Takao K and Sugita Y: Quantitative structure-cytotoxicity relationship of 3- $(\mathrm{N}$ cyclicamino)chromone derivatives. Anticancer Res 38(8): 4459 4467, 2018. PMID: 30061210. DOI: 10.21873/anticanres.12748

11 Sugimori N, Espinoza JL, Trung LQ, Takami A, Kondo Y, An DT, Sasaki M, Wakayama T and Nakao S: Paraptosis cell death induction by the thiamine analog benfotiamine in leukemia cells. PLoS One 10(4): e0120709, 2015. PMID: 25849583. DOI: 10.1371/journal.pone.0120709

12 Tomikoshi Y, Nomura M, Okudaira N, Sakagami H and Wakabayashi H: Enhancement of cytotoxicity of three apoptosisinducing agents against human oral squamous cell carcinoma cell line by benzoxazinotropone. In Vivo 30(5): 645-650, 2016. PMID: 27566085.

13 Calabrese EJ, Agathokleous E, Kozumbo WJ, Stanek EJ $3^{\text {rd }}$ and Leonard D: Estimating the range of the maximum hormetic stimulatory response. Environ Res 170: 337-343, 2019. PMID: 30616091. DOI: 10.1016/j.envres.2018.12.020

14 Zajączkowska R, Kocot-Kępska M, Leppert W, Wrzosek A, Mika J and Wordliczek J: Mechanisms of chemotherapy-induced peripheral neuropathy. Int. J Mol Sci 20(6): e1451, 2019. PMID: 30909387. DOI: $10.3390 /$ ijms20061451

15 Giannatempo P, Pond GR, Sonpavde G, Raggi D, Naik G, Galsky MD, Bellmunt J and Necchi A: The Impact of adding taxanes to gemcitabine and platinum chemotherapy for the firstline therapy of advanced or metastatic urothelial cancer: A systematic review and meta-analysis. Eur Urol 69(4): 624-633, 2016. PMID: 26497923. DOI: 10.1016/j.eururo.2015.09.051

16 Iijima Y, Yamada M, Endo M, Sano M, Hino S, Kaneko T and Horie N: Dysgeusia in patients with cancer undergoing chemotherapy. J Oral Maxillofac Surg Med Pathol 31(3): 214217, 2019. DOI: 10.1016/j.ajoms.2019.01.006

17 Park SS, Kim K, Kim SJ, Lee JH, Yoon SS, Mun YC, Lee JJ, Eom HS, Kim JS and Min CK: A Phase I/II, Open-label, prospective, multicenter study to evaluate the efficacy and safety of lower doses of bortezomib plus busulfan and melphalan as a conditioning regimen in patients with multiple myeloma undergoing autologous peripheral blood stem cell transplantation: The KMM103 Study. Biol Blood Marrow Transplant 25(7): 13121319, 2019. PMID: 30910603. DOI: 10.1016/j.bbmt.2019.03.016

18 Schlafer D, Shah KS, Panjic EH and Lonial S: Safety of proteasome inhibitors for treatment of multiple myeloma. Expert Opin Drug Saf 16(2): 167-183, 2017. PMID: 27841029. DOI: 10.1080/14740338.2017.1259310

19 Fang B, Song Y, Ma J and Zhao RC: Severe epidermal necrolysis after bortezomib treatment for multiple myeloma. Acta Haematol 118(2): 65-67, 2007. PMID: 17505132. DOI: $10.1159 / 000102604$

20 Bonomo P, Loi M, Desideri I, Olmetto E, Delli Paoli C, Terziani F, Greto D, Mangoni M, Scoccianti S, Simontacchi G, Francolini G, Meattini I, Caini S and Livi L: Incidence of skin toxicity in squamous cell carcinoma of the head and neck treated with radiotherapy and cetuximab. A systematic review. Crit Rev Oncol Hematol 120: 98-110, 2017. PMID: 29198343. DOI: 10.1016/j.critrevonc.2017.10.011

21 Bukamur HS, Mezughi H, Karem E, Shahoub I and Shweihat Y: Nivolumab-induced third degree atrioventricular block in a patient with stage iv squamous cell lung carcinoma. Cureus 11(6): e4869, 2019. PMID: 31417814. DOI: 10.7759/cureus.4869

22 Kawakami H, Zaanan A and Sinicrope FA: Microsatellite instability testing and its role in the management of colorectal cancer. Review. Curr Treat Options Oncol 16(7): 30, 2015. PMID: 26031544. DOI: 10.1007/s11864-015-0348-2

23 Neugut AI, Lin A, Raab GT, Hillyer GC, Keller D, O'Neil DS, Accordino MK, Kiran RP, Wright $\mathrm{J}$ and Hershman DL: FOLFOX and FOLFIRI use in stage IV colon cancer: Analysis of SEER-medicare data. Clin Colorectal Cancer 18(2): 133-140, 2019. PMID: 30878317. DOI: 10.1016/j.clcc.2019.01.005

24 Addeo R, Caraglia M, Vincenzi B, Luce A, Montella L, Mastella A, Mazzone S, Ricciardiello F, Carraturo M, Del Prete S and Sperlongano P: Efficacy and safety of cetuximab plus radiotherapy in cisplatin-unfit elderly patients with advanced squamous cell head and neck carcinoma. A retrospective study. Chemotherapy 64(1): 48-56, 2019. PMID: 31242489. DOI: $10.1159 / 000500714$
Received November 13, 2019

Revised November 19, 2019

Accepted November 20, 2019 